N-JILS

Nusantara

Journal of Information and Library Studies

Journal homepage: ojs.uninus.ac.id/index.php/JILS

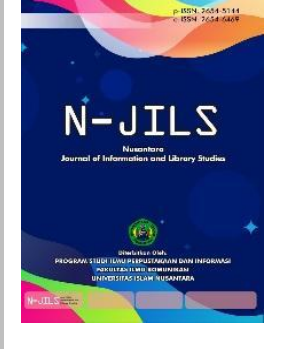

\title{
Eksistensi Produk Penerbitan Sebagai Sumber Literasi Mahasiswa UIN Syarif Hidayatullah Jakarta
}

\section{The Existence of Publishing Products as a Source of Student's Literacy in Syarif Hidayatullah University}

\section{Thalitha Sacharissa Rosyiidiani}

UIN Syarif Hidayatullah Jakarta

e-mail: thalithasacharissa.rosyiidiani@uinjkt.ac.id

\begin{tabular}{|c|c|}
\hline ARTICLE INFO & ABSTRACT \\
\hline $\begin{array}{l}\text { Article history } \\
\text { Received [November, 2020] } \\
\text { Revised [December, 2020] } \\
\text { Accepted [December, 2020] } \\
\text { Available Online [December, 2020] }\end{array}$ & $\begin{array}{l}\text { Campus is a place to study educated people who are familiar } \\
\text { with books. The existence of bookstores in the campus area is } \\
\text { very common. On the other hand, UIN Syarif Hidayatullah } \\
\text { Jakarta, as one of the well-known campuses close to the } \\
\text { capital, is not surrounded by bookstores. As a source of student } \\
\text { information, some students rarely buy printed books and rely } \\
\text { more on the internet. This condition resulted in several } \\
\text { bookstores around campus starting to close. Based on this } \\
\text { background, this study seeks to answer how the existence of } \\
\text { publishing products as a source of information for students, } \\
\text { especially students of UIN Syarif Hidayatulah Jakarta. This } \\
\text { article also discusses the fate of publishing today and how the } \\
\text { strategies used by publishers to maintain their existence amidst } \\
\text { the onslaught of digitization. The research method used is a } \\
\text { qualitative method through case studies. Researchers collected } \\
\text { data using document review, focus group discussion and } \\
\text { observation. The results of this study indicate a decline in sales } \\
\text { of printed books on the market. Nevertheless, publishing as a } \\
\text { company strives to produce strategic steps to increase public } \\
\text { buying interest in printed books. This research also focuses on } \\
\text { students reading interest in the digital era. This study } \\
\text { concludes six strategies that publishers must undertake to } \\
\text { increase the sales circulation of publishing products, namely } \\
\text { prioritizing visual design, collaborating with digital media, } \\
\text { reaching out to writers with viral work on social media. } \\
\text { increasing the scale of the readership by attracting clicks on a } \\
\text { managed website involves interaction between the reader }\end{array}$ \\
\hline
\end{tabular}


community and publishers and building cooperation with reputable reviewers.

Keywords: publishing strategy; source of literacy; digital era; bookstore; college student

Kata kunci: strategi penerbitan; sumber literasi; era digital; toko buku; mahasiswa

\begin{abstract}
ABSTRAK
Kampus merupakan tempat belajar para terdidik yang akrab dengan buku. Keberadaan toko buku di area kampus sangat lazim ditemukan. Di sisi lain, UIN Syarif Hidayatullah Jakarta sebagai salah satu kampus ternama yang dekat dengan ibukota tidak banyak dikelilingi oleh toko buku. Sebagai sumber informasi mahasiswa, sebagian dari mahasiswa sangat jarang membeli buku cetak dan lebih banyak mengandalkan internet. Kondisi ini mengakibatkan beberapa toko buku di sekitar kampus mulai tutup. Berdasarkan latar belakang tersebut, maka penelitian ini berupaya untuk menjawab bagaimana eksistensi produk penerbitan sebagai sumber informasi mahasiswa khususnya mahasiswa UIN Syarif Hidayatullah Jakarta. Artikel ini juga membahas tentang nasib penerbitan saat ini dan bagaimana strategi yang digunakan oleh penerbitan untuk tetap mempertahankan eksistensi di tengah gempuran digitalisasi. Metode penelitian yang digunakan adalah metode kualitatif melalui studi kasus. Peneliti mengumpulkan data menggunakan telaah dokumen, focus grup discussion dan observasi. Hasil penelitian ini menunjukkan adanya penurunan penjualan buku cetak di sejumlah toko buku. Kendati demikian, penerbitan sebagai perusahaan berupaya untuk menghasilkan langkahlangkah strategis untuk meningkatkan minat beli masyarakat terhadap buku cetak. Penelitian ini juga menyoroti tentang minat baca mahasiswa di era digital. Penelitian ini menyimpulkan enam strategi yang harus dilakukan penerbit untuk meningkatkan oplah penjualan. Strategi yang perlu dilakukan yaitu produk penerbitan perlu mengutamakan desain visual, berkolaborasi dengan media digital, menjangkau penulis dengan karya viral di media sosial, meningkatkan skala besaran pembaca dengan menarik klik atas situs website yang dikelola, melibatkan interaksi antara komunitas pembaca dan penerbit, serta membangun kerja sama dengan reviewer bereputasi baik.
\end{abstract}

(C) 2020 NJILS. All rights reserved.

\section{A. PENDAHULUAN}

Peradaban manusia mendorong kebutuhan komunikasi. Seiring dengan perkembangan zaman yang berkemajuan secara teknologi, cara-cara manusia berkomunikasi juga bertransformasi. Pada dasarnya, manusia melalui empat era komunikasi: oral, percetakan, elektronik dan digital. Masing-masing fase komunikasi diadopsi oleh sistem sosial tertentu pada kurun waktu ratusan bahkan ribuan tahun. Berawal dari perkembangan aksara melalui piktograf 
pada tahun 3100 SM, manusia mulai bisa membaca dan mengutarakan gagasan. Gagasangagasan kemudian diabadikan ke dalam bentuk tulisan. Peradaban tulis mengubah cara-cara komunikasi manusia secara lisan sehingga manusia tidak lagi mengandalkan ingatannya. Dengan tulisan, ilmu pengetahuan bisa diserbarkan ke sebanyak mungkin orang, namun penemuan mesin cetak Guttenbergh pada tahun 1450 mendorong penyebaran tulisan lebih cepat dan lebih luas jangkauan sebarannya. Penemuan mesin cetak juga merupakan awal dari era komunikasi percetakan yang melahirkan industri percetakan dan penerbitan (Ibrahim dan Iriantara, 2017).

Geliat kedua industri tersebut berkontribusi terhadap perkembangan ilmu pengetahuan. Tidak bisa dipungkiri, peradaban manusia sudah sangat lama bergantung pada percetakan dan penerbitan. Produk-produk penerbitan seperti buku menjadi rujukan para cendekiawan. Koran menjadi asupan informasi bergizi yang tersaji setiap hari. Sedangkan majalah merupakan sumber pendalaman minat dan bakat masing-masing individu. Perkembangan era komunikasi elektronik sempat menekan laju pertumbuhan industry media cetak dan penerbitan. Karena masyarakat bisa memperoleh informasi hanya dengan mendengar radio atau menonton televisi. Untuk terus bertahan di medan persaingan bisnis informasi, maka industri media cetak berkonvenvergensi dengan media elektronik. Seperti Kompas yang memproduksi versi cetak sekaligus menayangkan Kompas TV.

Digitalisasi mendorong eskalasi layanan informasi mampu hadir di setiap lini. Untuk mencari pengetahuan baru, seseorang hanya perlu mengarahkan kursor di laman search engine secara gratis dan dengan waktu singkat. Toko Gramedia melaporkan pada Ikatan Penerbit Indonesia (IKAPI) semenjak tahun 2012 hingga 2014, kurva penjualan buku cenderung turun. Menurut data tersebut, dari tahun 2012 hingga 2013, penjualan buku turun sebesar 1\%. Namun, penurunan dari 2013 hingga 2014 cukup signifikan. Jumlah buku yang terjual menurun sebesar 10\% (Handayani, 2019). Penyebab merosotnya penjualan oplah buku adalah karena orang semakin mengandalkan search engine. Di sisi lain, survei yang diselenggarakan oleh Asosiasi Penyelenggara Jasa Internet Indonesia (APJII) pada tahun 2018 menunjukkan jumlah pengguna internet meningkat dari 143,26 juta menjadi 171,17 juta. Artinya 64,8\% dari total penduduk Indonesia sudah terkoneksi internet. Dari segi usia, 91\% generasi millennials lebih sering menggunakan pengguna internet.

Dalam Jurnal Humaniora yang berjudul Literasi Media Internet Di Kalangan Mahasiswa dijelaskan tentang definisi generasi Y menurut Strauss dan Howe. Generasi Y ialah mereka yang 
lahir tahun 1982-2005 dan dikenal sebagai generasi millennium (Adiarsi, Stellarosa, \& Silaban, 2015). Berbeda dengan generasi sebelumnya, Generasi millenials memiliki kesamaan budaya yang dibentuk akibat pengalaman yang sama dalam berinteraksi menggunakan teknologi komunikasi media baru secara intens. Para millennials memiliki kebiasaan bermedia baik dalam menggunakan media maupun mengonsumsi media dengan pola yang sangat baru.

Lalu siapakah para millennials? Pada tahun 2019, sebagian dari golongan millennials bersatatus mahasiswa. Profesi ini menuntut seseorang untuk dekat dengan sumber ilmu pengetahuan karena di tangan mahasiswa perubahan sosial masyarakat bisa diwujudkan. Pada fase ini pula, pendidikan tidak selalu tentang apa yang dipresentasikan di mimbar-mimbar akademik, namun juga menuntut mahasiswa untuk membaca persoalan-persoalan di masyarakat. Oleh karena itu, mahasiswa lazim untuk terliterasi dengan berbagai sumber informasi. Salah satu penelitian yang disusun oleh Gracia Rachmi Adiarsi yang berjudul Literasi Media Internet di Kalangan Mahasiswa menyimpulkan bahwa mahasiswa yang mengakses internet di bawah 5 jam per hari umumnya sudah sibuk dengan pekerjaannya dan tidak terlalu intens menggunakan media Internet baik melalui smartphone maupun komputer. Berbeda dengan mahasiswa yang mengakses Internet di atas 5 jam per hari, hampir setiap saat mereka menggunakan Internet untuk media sosial dan pesan instan (instant messenger) melalui ponsel pintarnya (smartphone). (Adiarsi et al., 2015). Penelitian ini menggambarkan intensistas penggunaan internet sebagai sumber informasi dan literasi mahasiswa sudah sangat tinggi. Mengacu pada penelitian Literasi Media Internet Di Kalangan Mahasiswa, penelitian tentang bagaimana eksistensi produk penerbitan sebagai sumber informasi dan strategi apa yang dilakukan penerbit untuk menarik minat baca kaum milenial khususnya mahasiswa menjadi menarik untuk diteliti lebih lanjut. Tujuan penelitian ini untuk menggambarkan kemampuan industri penerbitan menghadapi era digitalisasi. Manfaat penelitian ini diharapkan mampu mendongkrak minat baca mahasiswa melalui berbagai sumber literasi. Baik online maupun cetak.

\section{B. TINJAUAN PUSTAKA}

Penerbitan memiliki kesamaan makna dengan publikasi yang dipahami sebagai "distribusi karya tulis atau cetak" atau informasi karya cetak atau tertulis. Pemahaman tentang penerbitan dimulai pada tahun 1650. Bahasa Prancis kuno menunjukkan bahwa kata "penerbitan" berasal dari kata "penerbit", yang berarti "tindakan publik". Penerbitan dapat didefinisikan 
sebagai proses menghasilkan dan menyebarkan informasi, bahkan jika informasi tersebut bersifat publik. Informasi tersebut dapat berupa karya seperti buku, majalah, surat kabar dan rekaman dalam bentuk cetak maupun elektronik. Fokusnya adalah membuat konten untuk konsumen. Berbeda dengan percetakan. Percetakan adalah proses yang digunakan untuk menyalin teks dan gambar (termasuk aktivitas) seperti penjilidan, layanan pembuatan piring dan pencitraan data. Fokusnya adalah menyalin konten dalam bentuk media (Sional, 2019).

Berdasarkan definisi tersebut, maka aktivitas dalam penerbitan lebih bersifat kreasi dan menitikberatkan pada muatan konten, sedangkan aktivitas pada percetakan lebih bersifat pada produksi dan replikasi hasil karya berisikan muatan konten tersebut. Dengan demikian, penerbitan dan percetakan memiliki aktivitas utama yang berbeda, tetapi sama-sama memiliki tujuan untuk memperoleh keluaran berupa produk informasi yang baik dan bermutu kepada masyarakat (Sional, 2019).

The Cairncross Review: A Sustainable Future for Journalism yang ditulis oleh Dame Frances Cairncross. Teori ini merumuskan cara-cara yang harus dilakukan industri penerbitan untuk terhindar dari disrupsi era digitalisasi. Penelitian ini dilatarbelakangi oleh masalahmasalah yang dialami para penerbit Inggris tentang menurunnya jumlah pembaca dan minimnya pasokan iklan ke dalam pundi-pundi perusahaan. Riset ini memaparkan bahwa para penerbit saat ini harus bersaing dengan kecerdasan mesin pencari dan sumber iklan digital. Ada beberapa langkah yang dilakukan para penerbit di Inggris untuk mengatasi tren penurunan sirkulasi, pembaca, dan pendapatan iklan: meningkatkan skala besaran pembaca dengan memaksimalkan klik, optimalisasi data pengguna, dan memaksimalkan pendapatan iklan (Future \& Journalism, 2019).

Teori ini menjelaskan bahwa platform digital memiliki dua fondasi: Pertama, ubiquitas dalam kehidupan masyarakat. Kedua, rantai pasokan iklan digital dan penguasaan terhadap data perilaku pengguna internet (Sudibyo, 2019). Selain itu, teori ini juga mengulas tentang makin banyaknya pembaca mengakses berita tidak secara langsung dari situs web penerbit, melainkan dari mesin pencari. Asumsinya adalah semakin banyak yang terlibat dalam penerbitan, makin sedikit keuntungan yang diperoleh penerbit. 


\section{METODE PENELITIAN}

Berangkat dari permasalahan menurunnya daya beli mahasiswa pada buku-buku perkuliahan, penelitian ini diolah dengan metode kualitatif dimana peneliti menelusuri sebabsebab minimnya toko buku yang ada di sekitar kampus. Sumber data penelitian ini berasal dari focus grup discussion (FGD) yang melibatkan 30 mahasiswa tingkat akhir program studi Komunikasi dan Penyiaran Islam. Data sekunder diperoleh dari wawancara tidak terstruktur, survey menggunakan aplikasi google form dan dokumentasi yang dilakukan pada bulan September-Oktober 2019. Peneliti juga melakukan beberapa model eksperimen di tengah-tengah diskusi tentang bagaimana kemampuan mahasiswa menangkap dan mengulas kembali informasi dalam bentuk notasional.

Peneliti berupaya untuk mereduksi data-data yang diperoleh dengan mempertimbangkan rumusan masalah penelitian. Setelah melakukan reduksi data, peneliti mencoba untuk mengelaborasi pernyataan subyek penelitian ke dalam bentuk tabel dan gambar. Selanjutnya, peneliti melakukan analisis data. Terdapat tiga tahapan yang dilakukan; Pertama, reduksi data yaitu merangkum, mengumpulkan data terkait penelitian ini berupa data focus group discussion, data pengunjung Gramedia, data tentang penerbitan dari hasil telaah literatur. Kedua, penyajian data yaitu menyajikan data dalam bentuk tabel dan grafik diikuti dengan penjelasan yang terperinci sesuai dengan kajian teori. Terakhir adalah penarikan kesimpulan yang merangkum temuan penelitian.

\section{HASIL DAN PEMBAHASAN}

Gempuran digitalisasi mengakibatkan sejumlah media cetak gulung tikar dan beberapa industry penerbitan tidak aktif melakukan produksi dan distribusi. Berdasarkan penelitian yang dilakukan oleh IKAPI di tahun 2015 menunjukkan bahwa Gramedia menguasai pasar penerbitan sebanyak 61\%. Pada kurun waktu 2013-2014, gramedia mengalami penurunan penjualan sebanyak 3.320.000.000 eksemplar (Simamora, 2019). 


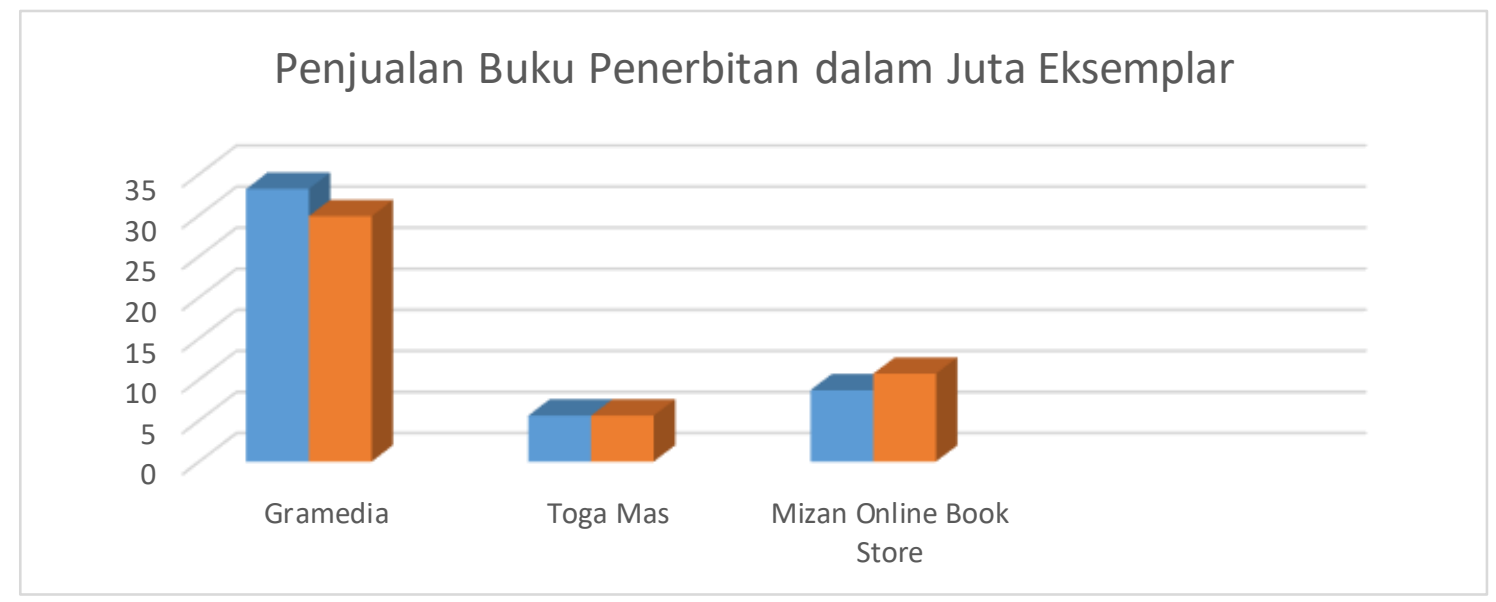

Gambar 1. Penjualan Buku Penerbitan di Toko Buku Gramedia, Togamas, dan Mizan Online Sumber: Tirto.id, 2019

Laporan Jumlah Pengunjung Gramedia 2016-2019 yang diperoleh peneliti menyatakan jumlah pengunjung Toko Buku Gramedia Matraman Jakarta Timur juga mengalami penurunan yang signifikan. Di tahun 2016, satu toko buku Gramedia mencatat jumlah pengunjung sebanyak 107.078 orang. Pada tahun 2017 mencapai 90. 253 orang. Penurunan pengunjung secara dramatis terjadi di tahun 2018 yang hanya berjumlah 2026 orang. Di tahun 2019, jumlah pengunjung hanya sekitar 1888 orang.

\section{Jumlah Pengunjung Toko Buku Gramedia 2016- 2019}

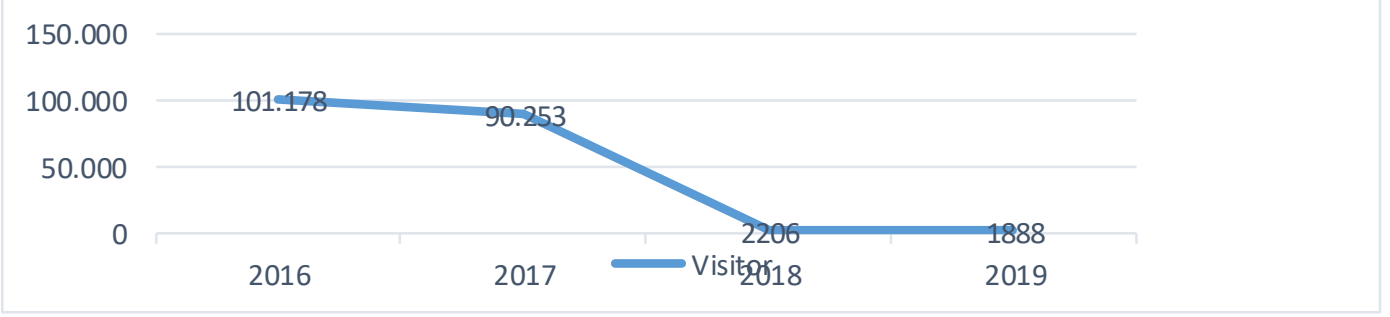

Gambar 2. Laporan Jumlah Pengunjung Toko Buku Gramedia Matraman Sumber: Tirto.id, 2019

Buku-buku cetak bertema pendidikan masih menjadi primadona dalam kurva penjualan. Penjualan buku pelajaran atau buku pendidikan di Indonesia memang menarik untuk digeluti karena besarnya potensi penjualan buku pelajaran dari tingkat Taman Kanak-Kanak hingga universitas. Pasar buku ajar atau buku teks perguruan tinggi memiliki potensi pengembangan dari tahun ke tahun karena banyaknya populasi mahasiswa dan juga jumlah perguruan tinggi, 
baik di bawah Kementerian Ristek Dikti maupun Kementerian Agama.(Trim, 2015). Di sisi lain, survey yang dilakukan peneliti menunjukkan bahwa dalam kurun waktu 1 tahun, sebanyak 63, 6\% mahasiswa hanya membeli antara 1-3 buku saja. Hanya 36,4\% mahasiswa yang mampu membeli buku sebanyak 5 eksemplar dalam 1 tahun. Sisanya, mahasiswa lebih banyak mengandalkan perpustakaan dan internet untuk mengakses buku (Rosyiidiani, 2019).

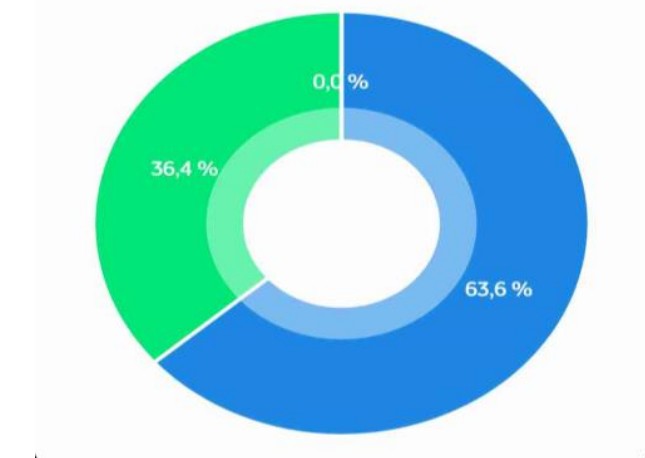

Gambar 3. Diagram Prosentase Jumlah Buku yang Dibeli Mahasiswa Selama 1 Tahun Sumber: Rosyiidiani, 2019

Tidak hanya buku pendidikan di tingkat perguruan tinggi saja, buku ajar SD dan SMP mengalami penurunan oplah penjualan. Penurunan itu sebesar 31,25\% produk SD pada range 50.000 - 100.000 eksemplar dan 31,25 \% produk SMP pada range 100.000 - 300.000 eksemplar. Perubahan-perubahan itu disebabkan oleh berbagai faktor, di antaranya faktor internal dari penerbit sendiri dan faktor eksternal, baik dari pemerintah maupun masyarakat. Berikut adalah hasil wawancara mengenai faktor-faktor perubahan tersebut. Perubahan produksi itu terdiri atas kenaikan dan penurunan jumlah judul buku pada jenjang-jenjang pendidikan tertentu. Terjadi Penurunan produksi pada buku SD dan SMP tersebut disebabkan buku-buku bidang studi pokok untuk jenjang tersebut dijadikan sebagai BSE pada tahun pertama kebijakan mengenai BSE (Permendiknas No.2 Tahun 2008). Hal itu terjadi pada penerbit-penerbit skala kecil yang dari perhitungan bisnis mereka tidak menghasilkan keuntungan disebabkan harga BSE yang sangat murah. Namun, untuk penerbit-penerbit skala besar yang memperoleh pemesanan dengan jumlah eksemplar memadai, tetap memproduksi BSE karena tetap bisa mengambil keuntungan meskipun keuntungannya relatif kecil. Selain keuntungan yang relatif kecil, penurunan produksi buku SD dan SMP disebabkan oleh tata niaga buku pelajaran yang diatur dengan Permendiknas No 2 tahun 2008 (Simamora, 2019). 
Meredupnya oplah penjualan buku cetak tentunya berimbas pada pendapatan penerbit. Sehingga penerbit harus mencari celah untuk mengatasinya. Salah satu alternatif meningkatkan penjualan adalah melakukan konvergensi dari penjualan buku melalui toko fisik ke penjualan dalam bentuk toko digital. Beberapa toko buku digital yang kini mulai berkiprah di Indonesia, di antaranya Qbaca (Telkom), Bookmate Indonesia (Indosat), Wayang Force, Scoop, Aksara Maya, Buqu.Selain itu, beberapa penerbit mengembangkan e-bookstore sendiri, yaitu e-Rosda (Rosdakarya), Gramediana (Gramedia), Lumos (Mizan), UI Press, IPB Press, Penerbit ITB, Unair Press, dan Unsri Press. Ini mengindikasikan bahwa penerbit sudah mulai memikirkan perubahan yang akan terjadi seiring dengan kemajuan dalam bidang komunikasi sehingga media baca konvensional mulai mengalami pergeseran ke media digital. Akan tetapi, dari penerbit yang sudah bergerak ke arah $e$-book, persentase judul buku mereka yang telah dikonversi menjadi $e$ book masih sangat rendah (Trim, 2015).

Proporsi terbesar adalah 5\% dari judul buku yang diterbitkan yang dibuatkan versi $e$ book-nya. Artinya, dari penerbit memang sudah melirik e-book, tampak penerbit masih terlihat sangat membatasi konversi sehingga persentase penerbitan e-book masih sangat kecil. Kondisi ini menyebabkan minimnya mahasiswa yang mengakses buku digital karena mereka kesulitan untuk menemukan buku digital yang sesuai dengan kebutuhan belajar mereka. Survey peneliti yang melibatkan 100 responden menggambarkan sebanyak 45,45\% mahasiswa tidak sering mengakses $e$-book dan hanya 9,09\% mahasiswa yang mengakses $e$-book secara rutin.

Di era digitalisasi, mahasiswa saat ini tetap tidak bisa dipisahkan dengan buku sebagai penunjang proses pembelajaran mereka. Buku fisikal masih tetap menjadi primadona mahasiswa dibandingkan dengan buku digital. Berdasarkan Focus Group Discussion antara peneliti dan mahasiswa untuk menjawab pengalaman membaca dari segi kenyamanan, ditemukan bahwa mahasiswa generasi millennials masih kesulitan untuk beradaptasi dengan e-book atau sumber bacaan yang berasal dari internet. Peneliti melakukan eksperimen kepada 18 mahasiswa yang dibagi menjadi 2 kelompok. Kelompok pertama diharuskan untuk membaca artikel tentang komunikasi yang di cetak di atas satu lembar kertas. Kelompok kedua diharuskan untuk membaca artikel serupa namun menggunakan versi digital yang ditulis di salah satu kanal media online.

Masing-masing kelompok diberi waktu 5 menit untuk membaca dan mencerna informasi dalam artikel tersebut kemudia diharuskan untuk menjelaskan secara singkat isinya. Hasil dari 
eksperimen ini adalah bahwa kelompok kedua dapat membaca artikel lebih cepat dibandingkan kelompok pertama. Akan tetapi, ketika diminta untuk menjelaskan isi dari artikelnya, kelompok pertama memiliki kemampuan yang jauh lebih baik dalam pemaparan. Secara sederhana, hasil pengamatan tersebut dijelaskan pada table berikut ini:

Tabel 1. Aktivitas Membaca Mahasiswa pada Media Cetak dan Digital

\begin{tabular}{|l|l|l|}
\hline Komponen Penilaian & \multicolumn{1}{|c|}{ Kelompok 1 (Versi Cetak) } & Kelompok 2 (Versi Digital) \\
\hline Kecepatan Membaca & $>5$ menit & $<5$ menit \\
\hline Pemaparan Informasi & Lebih banyak informasi & Terbata-bata \\
\hline Pengalaman Membaca & Membutuhkan banyak waktu & Fokus mudah teralihkan \\
\hline
\end{tabular}

Fakta tersebut semakin menguatkan asumsi bahwa tidak banyak yang berubah dari pola membaca mahasiswa millennials. Mahasiswa millennials masih banyak yang bergantung pada buku cetak. Untuk mendapatkan akses pembelian buku, 57,1\% mahasiswa masih banyak yang mengandalkan toko buku fisik. Sebagian ada pula yang mengandalkan marketplace online seperti di Shopee, Bukalapak, dan Tokopedia sebesar 28,6\%. Ada juga yang memilih membeli buku melalui media sosial seperti instagram, face-book, dan whatsapp sebanyak 14,3\%.

Keputusan mahasiswa untuk membeli buku cetak dari penerbit resmi ada yang dilatarbelakangi oleh kewajiban dari dosen, atau memenuhi kebutuhan referensi utama dalam mengerjakan karya akademik ketika referensi yang dicari tidak mereka temukan di perpustakaan. Selama ada peluang untuk mendapatkan buku secara gratis, maka mahasiswa cenderung menjadikan aktivitas membeli buku sebagai pilihan terakhir. Alasan lain yang umum dinyatakan oleh responden adalah harga dan kualitas buku yang kurang bersahabat.

Meskipun daya beli mahasiswa terhadap buku tidak cukup tinggi, hal tersebut tidak menyurutkan keyakinan mahasiswa terhadap eksistensi buku cetak produk penerbitan di era digital. Berdasarkan hasil diskusi peneliti, sebagian besar subyek penelitian pada penelitian ini menyatakan bahwa mereka optimis terhadap eksistensi penerbitan di era digitalisasi.

"Menurut saya masa depan percetakan akan tetap optimis walaupun di masa modern seperti ini mengapa demikian karena memang tidak memungkiri bahwa industri percetakan masih dibutuhkan sampai saat ini walaupun akses internet yang memang sekarang sudah semakin berkembang bisa membantu dalam hal penyimpanan data, proses administrasi dll tetapi percetakan tidak bisa dihilangkan mengapa ? Contoh misalkan kita sudah selesai mengerjakan skripsi, file skripsi itu bisa kita simpan di melalui digital atau menggunakan akses internet tetapi alangkah lebih baiknya kita juga mncetaknya karna apa karen data data yang ada internet suatu saat bisa saja dilihat orang 
lain, atau hilang atau mungkin orang lain dapat menyelidiki mengenai data yang ada karena memang alasan keamanan nah. Mungkin menurut saya industri percetakan tidak bisa dipisahkan dari kehidupan kita dan percetakan akan terus ada mengingat kebutuhan kebutuhan yang ada juga." (Angga Surya Pratomo, Mahasiswa KPI VII E, Wawancara, Oktober, 2019)

"Masa depan percetakan jika dilihat dari fakta yang ada pada saat ini mungkin akan mengalami kemunduran karena masyarakat sendiri lebih memilih menggunakan digital atau media online. Namun, penerbit bisa saja beralih dari percetakan menjadi penerbitan secara digital atau online." (Mega Julia, Mahasiswa KPI VII B, Wawancara, Oktober, 2019)

"Masa depan media percetakan dan penerbitan untuk koran dan sebagainya sedikit bergerak pesimis karena melihat situasi kondisi yang semua orang lebih memilih mencari informasi melalui media digital. Berbeda halnya dengan percetakan dan penerbitan buku bacaan, masih akan bergerak optimis karena tidak semua buku berada di media digital dan tidak semua berupa $e$-book, dan orang-orang pasti akan masih mencari buku-buku bacaan tersebut karena masih banyak sekali peminatnya." (Mariya Ulfa Almunawwaroh, Mahasiswa KPI VII A, Wawancara, Oktober, 2019)

Mahasiswa meyakini bahwa penerbitan adalah perusahaan besar yang pasti sudah mengkalkulasi untung rugi dan akan terus berupaya untuk menghasilkan langkah-langkah strategis untuk meningkatkan minat beli masyarakat terhadap buku cetak. Penerbit yang berkolaborasi dengan digital akan menjangkau pasar yang lebih besar dibandingkan era sebelumya yang hanya mengandalkan toko buku fisik dengan operasional besar. Penerbit besar yang sudah memprediksi digital attack akan mampu bertahan di tengah disrupsi, sedangkan penerbit yang masih menggunakan cara-cara konvensional lambat laun tidak akan bisa bertahan.

"Menurut saya percetakan dan penerbitan mempunya pasar dan konsumen tersendiri walaupun jaman trus berkembang mereka punya tempat tersendiri dalam bergerak." (Natasya Hikma Kamila, Mahasiswa KPI VII D, Wawancara, Oktober, 2019)

"Menurut saya para penerbit dan percetakan sebenarnya tidak perlu pesimis atau takut akan ancaman dari dunia digital ini. Seharunya hal ini justru menjadi tantangan penerbit an percetakan untuk lebih berinovasi dalam menerbitkan buku-buku bagus dan berkualitas." (Asyyifa, Mahasiswa KPI VII C, Wawancara, Oktober, 2019)

“...tergantung kepada yang memiliki modal penerbitan/percetakan harus lebih bisa berinovasi seiring kemajuan teknologi agar tidak tergerus oleh zaman. Apalagi tentunya mereka adalah perusahaan yang punya cukup modal untuk membuat terobosan." (Nurul Jannatul Yusofi, Mahasiswa KPI VII D, Wawancara, Oktober, 2019) 
Ketika alat tulis ditemukan, tren komunikasi bergeser menjadi kertas yang berisi pesan dikirim melalui burung merpati. Buku pun lahir seiring dengan perkembangan mesin cetak dan penerbitan. Berlanjut dengan teknologi komunikasi lainnya: telegraf, telepon, surat kabar, majalah, radio, televisi, komputer dan kini, internet. Namun, berbagai media di atas tidak dapat saling menggantikan peran satu sama lain. Buku tidak digantikan oleh surat kabar. surat kabar tidak digantikan oleh radio, radio tidak digantikan oleh televisi, dan televisi tidak digantikan oleh komputer (Bakti, 2014).

Setiap teknologi komunikasi yang berhasil diadaptasi oleh kelompok sosial masyarakat membutuhkan waktu penyesuaian yang tidak sebentar. Peradaban kertas yang sudah berkembang sejak 105 masehi dan pengalaman membaca umat manusia melalui buku secara fisik tidak mudah diubah dalam sekejap meskipun media digital mulai digunakan secara massif di berbagai aktivitas kehidupan. Keterkaitan antara sekumpulan tulisan di lembaran kertas yang dibukukan dengan kebiasaan manusia terhadapnya merupakan budaya yang berjalan ribuan tahun dan diwariskan secara turun temurun kepada generasi umat manusia. Optimalisasi internet di ranah pendidikan masih belum mencapai satu dekade. Oleh karena itu, wajar jika generasi millennial khususnya mahasiswa belum bisa memaksimalkan penggunaan e-book sebagai sumber bacaan alternatif. Kebanyakan dari mereka enggan membaca $e$-book dari media internet, mereka hanya mengunduhnya saja (Adiarsi et al., 2015).

Oleh karena itu, buku cetak penerbitan masih memiliki peluang di kalangan pembaca millennial. Kendati demikian, untuk meraih target pasar millennial khususnya mahasiswa yang saat ini sangat terafiliasi dengan internet, memerlukan pendekatan yang berbeda. Berdasarkan hasil diskusi dengan subyek penelitian dan merujuk pada teori The Cairncross Review: A Sustainable Future for Journalism, beberapa tahapan strategi yang bisa dilakukan penerbit untuk menjangkau mahasiswa adalah sebagai berikut: pertama, mengutamakan desain visual. Ada dua dimensi utama yang memengaruhi penerbitan. Pertama, dimensi verbal berupa pemilihan kata-kata dalam konten. Kedua, dimensi visual tentang bagaimana produk penerbitan ditampilkan. Di era digitalisasi, yang harus menjadi perhatian penerbit adalah bagaimana menghadirkan pengalaman membaca yang berbeda bagi pembacanya. Para millennials seperti mahasiswa adalah generasi 'net geners' yang memiliki keunikan tersendiri (Nureni, Pramiyanti, \& Putri, 2013). Sebagaimana yang dipaparkan oleh Montgomery (2000), “as early adopters of new media, youth are in many ways the defining users of the new mediall. Media baru seperti 
internet mengakomodir antara teks, gambar, audio, dan video yang bisa ditampilkan sekaligus. Meskipun buku cetak tidak bisa menghasilkan video, namun bisa dikembangkan secara visual. Semakin menarik visual suatu buku, maka semakin tinggi kemungkinan buku itu laku di pasaran. Desain visual ini bisa diaplikasikan pada cover buku, pemilihan kertas, dan bentuk tulisan, kata-kata mutiara dan lain sebagainya.

Kedua, berkolaborasi dengan media digital. Perkembangan tekhnologi komunikasi dan informasi menuntut penerbit untuk segera mengambil tindakan antara melakukan penyesuaian atau mempertahankan tradisi yang sudah ada. Pangsa pasar millennials khusunya mahasiswa akan lebih mudah dijangkau melalui media digital. Oleh karena itu, pihak penerbitan harus mengambil bagian dalam digitalisasi informasi. Caranya dengan membuat situs toko buku online yang dikelola sendiri atau mengelola akun di media sosial. Hal ini juga akan memudahkan penerbit untuk memperoleh iklan digital. Hal yang perlu ditekankan dalam konvergensi media adalah harus dipastikan bahwa situs digital yang hendak dikelola bersifat 'friendly user'.

Ketiga, menjangkau penulis dengan karya viral di media sosial. Antara penulis dan penerbit memiliki hubungan yang saling menguntungkan baik sebelum atau sesudah era digitaliasi berkembang. Namun formula hubungan tersebut sedikit mengalami perubahan. Sebelum era digital, penulis yang kurang berpengalaman akan kesulitan untuk menerbitkan karyanya di penerbit resmi yang bergengsi. Melalui wattpad, penulis-penulis pemula mulai bermunculan. Keuntungan yang diperoleh oleh penulis ketika mempublikasikan karyanya di media digital yaitu tulisan bisa dibaca oleh banyak orang, mendapatkan masukan dari pembaca mengenai tulisan yang dibuat, dan membuat semangat menulis karena biasanya akan ditagih oleh pembaca ketika menarik. Bagi penerbit, keuntungan yang diperoleh tentunya penerbit tidak perlu berspekulasi dengan proyek penulis yang masih belum tentu menguntungkan. Tulisan yang viewer-nya mencapai jutaan di media digital, kemungkinan akan banyak yang membeli bukunya lebih besar. Bagi pangsa pasar mahasiswa yang cenderung mengikuti tren, karya-karya viral di media digital akan mengundang rasa penasaran dan ketertarikan untuk membeli bukunya.

Keempat, penerbit perlu meningkatkan skala besaran pembaca dengan menarik klik atas situs web yang dikelola. Makin banyak pengguna situs web, makin menarik suatu situs tersebut di mata pengiklan. Penerbit yang telah mengelola situsnya sendiri bisa memancing minat 
pembaca dengan 'clickbait' dengan judul-judul yang sensasional. Meskipun demikian, menurut Cairncross memiliki skala pembaca yang besar saja tidak cukup untuk mendatangkan iklan digital. Klik bukan satu-satunya yang harus dikejar penerbit. Penggunaan ad-blocker di antara pengguna internet juga memperparah jumlah pendapatan iklan digital. Makin popular penggunaan ad-blocker, makin besar jumlah klik yang dibutuhkan untuk mendapatkan satu transaksi iklan (Sudibyo, 2019).

Kelima, melibatkan interaksi antara komunitas pembaca dan penerbit. Komunitas baca bukanlah hal baru dalam dunia penerbitan. Di era digital saat ini, bentuk-bentuk dukungan dari komunitas harus bergerak ke arah yang lebih proaktif. Penggunaan tagar di media sosial menjadi kunci keberhasilan tingkat kognisi masyarakat terhadap karya penerbitan. Penerbit juga selayaknya merespon dengan cepat apa-apa saja yang menjadi pertimbangan komunitas dan berkolaborasi dengan kegiatan bedah buku atau penyelenggaraan festival buku. Tujuan dari jaringan antara penerbit dan pembaca memungkinkan penerbit untuk menggalang donasi dari pembaca setia. Donasi tersebut bisa digunakan untuk menerbitkan konten-konten berkualitas sesuai dengan karakteristik dan keinginan pembaca.

Keenam, membangun kerja sama dengan reviewer bereputasi baik. Strategi ini cukup baru di kalangan penerbitan. Era digital memungkinkan orang untuk menjangkau segala hal yang berada di luar jangkauannya dengan cepat dan mudah. Beberapa penerbit memanfaatkan jaringan reviewer yang diambil dari para influencer media sosial atau millennials yang memiliki banyak followers. Reviewer bertugas untuk memberikan sedikit spoiler informasi terkait buku yang akan diiklankan dengan imbalan berupa uang atau buku yang diiklankan. Cara-cara yang dilakukan reviewer adalah dengan memposting foto buku dengan kualitas baik diiringi caption yang menggugah keingintahuan calon pembaca untuk membeli buku tersebut.

\section{E. KESIMPULAN DAN SARAN}

Industri penerbitan masih mampu bertahan di era digital saat ini. Dari penelitian ini tergambar bahwa meskipun bahwa terjadi penurunan kunjungan dan penjualan produk-produk penerbitan, mahasiswa masih mengandalkan buku cetak sebagai sumber literasi. Mahasiswa pada penelitian ini menyadari bahwa membaca buku secara fisik lebih memudahkan mereka dalam menyerap informasi. 
Industri penerbitan masih ada di hati banyak orang. Sejarahnya yang panjang pada peradaban umat manusia membuat produk-produk penerbitan sangat sulit tergantikan. Penerbit yang sudah memperkirakan dan mempersiapkan digitalisasi akan mudah berbenah diri dengan mempersiapkan starategi digitalisasi. Untuk mengatasi disrupsi, penerbit disarankan untuk berkonvergensi dengan digital dan mengelola data pengguna pada situs agar bisa dimanfaatkan sebagai daya tarik iklan digital. Sedangkan untuk menjangkau pasar milenial, khususnya mahasiswa, penerbit bisa berkolaborasi dengan berbagai pihak di antaranya platform media sosial, komunitas pembaca, dan para reviewer buku dari kalangan influencer.

\section{DAFTAR PUSTAKA}

Adiarsi, G. R., Stellarosa, Y., \& Silaban, M. W. (2015). Literasi Media Internet di Kalangan Mahasiswa. Humaniora, 6(4), p. 470-482. https://doi.org/10.21512/humaniora.v6i4.3376.

Bakti, A. F. (n.d.). (2014). Trendsetter Komunikasi di Era Digital: Tantangan dan Peluang Pendidikan Komunikasi dan Penyiaran Islam. Jurnal Komunikasi Islam 4 (1), p. 21-44. https://doi.org/10.15642/jki.2014.4.1.\%25p

Cairncross, Dame Frances. (2019). The Cairncross Review: A Sustainable Future for Journalism. (https://www.mendeley.com/catalogue/9005c469-3d2c-3194-a09a-

b28791bc7a8b/?utm_source=desktop\&utm_medium=1.19.4\&utm_campaign=open_catalog\&userDocumen tId=\%7B5bd3bb9b-e2a1-464f-b7b9-ddcff948a726\%7D)

Downing, John, dkk. (1995). Questioning The Media. A Critical Introduction. London.: Sage Publications Ltd.

Handayani, Maulida Sri. Melawan Goliat Perdagangan Buku. Diakses pada tanggal 3 September 2019 dari https://tirto.id/835.

Ibrahim, Idi Subandy \& Yosal Iriantara. (2017). Komunikasi Yang Mengubah Dunia Revolusi dari Aksara Hingga Media Sosial. Bandung: Simbiosa Rekatama Media.

Nureni, R., Pramiyanti, A., \& Putri, I. P. (2013). Perilaku Remaja Dalam Menggunakan Media Baru: Pemetaan Habit Media Baru Remaja Daerah Sub Urban Kota Bandung (Kabupaten Bandung). Jurnal Sosioteknologi, 12(30), p. 461-474. https://doi.org/10.5614/sostek.itbj.12.30.1

Simamora, B. (2019). Studi tentang Perkembangan Industri Penerbit Buku Sekolah Setelah Terbitnya Buku Sekolah Elektronik. P. S., Negeri, P., \& Kreatif, M. (n.d.). Jurnal Publi Prenenur, 1(1), p. 12-25. https://doi.org/10.46961/jip.v1i1.21.g11

Sional, N. A. (2019). Rencanan Pengembangan Penerbitan Nasional 2015-2019. Jakarta: Pt. Republik Solusi.

Sudibyo, Agus. (2019). Jagat Digital Pembebasan dan Penguasaan. Jakarta: PT. Gramedia.

Trim, Bambang dkk. (2015). Industri Penerbitan Buku Indonesia dalam Data dan Fakta. Jakarta:IKAPI.

Wilson, C., Grizzle, A., Tuazon, R., Akyempong, K., \& Cheung, C.-K. (2011). Curriculum for Teachers Curriculum for Teachers. Policy Studies. France: UNESCO. 